\title{
STUDI KOMPARATIF TEORI KONFLIK JOHAN GALTUNG DAN LEWIS A. COSER
}

\section{A COMPARATIVE STUDY OF CONFLICT THEORY OF JOHAN GALTUNG AND LEWIS A. COSER}

\author{
Ali Mursyid Azisi \\ Universitas Islam Negeri Sunan Ampel
}

alimursyidazisi@gmail.com

\begin{abstract}
ABSTRAK: Artikel ini mengkaji tentang teori konflik yang diusung oleh Johan Galtung dan Lewis A Coses dengan pendekatan studi komparatif. Isi pembahasan artikel ini adalah mengkaji bagaimana kerangka teori yang dikemukakan kedua tokoh tersebut beserta pemahamannya dalam realitas kehidupan. Langkah yang digunakan dalam mengumpulkan data dalam penelitian ini yaitu menggunakan studi pustaka/library research. Metode penelitian ini bersifat kualitatif deskriptif dengan pendekatan penelitian komparatif. Penelitian komparatif akan menemukan persamaanpersamaan dan perbedaan-perbedaan dari pendapat yang diusung kedua tokoh tersebut dalam memandang konflik pada realitas kehidupan. Artikel ini penting dikaji secara mendalam karena dengan mengetahui bagaimana kedua teori tersebut berpengaruh dan beroperasi. Diharapkan hasil penelitian ini akan menuai pemahaman bagi para akademisi dan menjadi tambahan perbendaharaan ilmu dalam bidang managemen konflik. Maka dengan begitu, hasil penelitian ini akan mempermudah siapapun dalam mencari referensi keilmuan yang memiliki keterkaitan dengan teori ini.
\end{abstract}

Kata Kunci: Teori Konflik, Johan Galtung, Lewis A. Coseri.

ABSTRACT: This article examines the comparative study of conflict theory by Johan Galtung and Lewis A. Coser. In it examines how the theoretical framework put forward by the two figures and their understanding in the reality of life. The steps used in collecting data in this research are using literature study/library research with qualitative methods. From the opinion of the two figures, they have their own characteristics and differences in viewing conflict in the reality of life. This article is very important to be studied in more depth, because knowing how these two theories influence and operate, will later gain understanding for academics and become an additional treasury of knowledge in the field of conflict management. That way it will make it easier for anyone to find scientific references that are related to this theory.

Keyword: Conflict Theory, Johan Galtung, Lewis A. Coser.

\section{A. PENDAHULUAN}

Dalam realitas kehidupan di tengah masyarakat yang beragam watak, karakter, perilaku ataupun budayanya akan menjadikan suatu masyarakat memiliki warna tersendiri dari adanya keragaman tersebut. Mulai dari adanya suatu kegiatan yang mengusung tema atau kegiatan tertentu yang menjadikan interaksi sosial di masyarakat dapat terjalin baik dan memunculkan rasa solidaritas di antara masyarakat itu sendiri. Dalam kehidupan ini, wawasan tentang perbedaan sangat penting untuk dipahami, sebab 
dari luasnya pemahaman wawasan tentang perbedaan, maka nantinya akan menyatukan persepsi demi kepentingan bersama yang terikat dalam harmonisasi masyarakat.

Indonesia dikenal dengan kaya akan keragaman suku bangsa, agama, budaya dan bahasa. Kemajemukan dalam masyarakat memiliki dampak positif tersendiri, namun di balik itu, terdapat juga dampak-dampak negatif yang membayangi dari kemajemukan tersebut. ${ }^{1}$ Dampak dari kemajemukan tersebut tidak terlepas dari adanya suatu konflik yang bisa saja terjadi kapanpun, di manapun, dan siapapun, entah itu mengatasnamakan antar kelompok maupun individu. ${ }^{2}$ Di berbagai belahan duniapun suatu konflik kerap terjadi, bahkan di antaranya menggunakan cara kekerasan, seperti halnya yang hingga kini tetap berlanjut yakni konflik Palestina dan Israel. Hal tersebut menunjukkan bahwa konflik memang tidak bisa dipisahkan dengan kehidupan bermasyarakat, baik yang muncul atas dasar kekuasaan, individu, antar kelompok dan sebagainya.

Suatu konflik dapat terjadi karena tidak adanya keserasian atau terdapat pandanganpandangan yang saling bertolak belakang. Namun hal yang paling berbahaya dari suatu konflik adalah ketika konflik tersebut dimanifestasikan ke dalam suatu tindakan kekerasan secara fisik terhadap kelompok tertentu yang disebabkan beberapa faktor seperti intoleran, kemiskinan, ketidaksetaran dan lainnya. ${ }^{3}$ Lain halnya dengan konflik yang tidak atau bukan berupa kekerasan/tindakan secara fisik, misalnya hanya sekedar kompetisi yang memperlihatkan keunggulannya dibandingkan lawan yang tujuannya menghancurkan lawan itu sendiri.

Oleh karenanya dari adanya suatu konflik, baik dalam skala mikro maupun makro yang tersebar di berbagai sudut dunia, maka perlu untuk diketahui apa penyebab konflik dan bagaimana konflik tersebut dipetakan. Dalam kajian beberapa tokoh pendahulu tentang konflik sangat menarik untuk dikaji lebih dalam. Misalnya teori konflik yang dikemukakan oleh Johan Galtung dengan teori ABC-nya dalam memandang realitas kehidupan yang memiliki latar belakang cara pandang tersendiri terhadap konflik. ${ }^{4}$ Atau

\footnotetext{
${ }^{1}$ Indra Gunawan, Anton Saetban, dan Aiman Faiz, "Enhancing Religious Tolerance through Educators' Behaviors,” JPIS: Jurnal Pendidikan Ilmu Sosial 28, no. 1 (2019): 38.

${ }^{2}$ Nour Zattullah, "Konflik Sunni-Syiah di Sampang Ditinjau dari Teori Segitiga Konflik Johan Galtung”, Jurnal Ilmu Budaya, vol. 9, no. 1, 2021, 87.

${ }^{3}$ Fitriani, dkk, "Membangun Relasi Umat Beragama Pasca Konflik Agama di Tanjungbalai", Studia Sosia Religia, vol. 3, no. 1, Januari-Juni 2020, 53.

${ }^{4}$ Refia Juniarti Handrastin, Budi Purwoko, "Studi Kasus Dinamika Psikologis Konflik Interpersonal Siswa Merujuk Teori Segitiga ABC Konflik Galtung dan Kecenderungan Penyelesaiannya pada Siswa Kelas XII Jurusan Multimedia (MM) di SMK Mahardika Surabaya", Jurnal BK Unesa, vol. 4, no. 2, 2014, 368.
} 
pun teori konflik yang dikemukakan oleh Lewis A. Coser dengan definisi atau teori mengenai konflik yang memiliki ciri khas tersendiri pula. Dari kedua tokoh di atas tentu memiliki unsur kerangka dan cara pandang tersendiri dalam memotret sebuah konflik.

Maka dari itu sangat penting artikel ini dikaji secara mendalam dengan tujuan agar mengetahui bagaimana teori konflik yang diusung oleh kedua tokoh tersebut, baik dari Johan Galtung maupun Lewis A. Coser. Pada pembahasan ini terdapat rumusan masalah yang akan dikaji secara mendalam yaitu: apa itu konflik/teori tentang konflik, bagaimana teori konflik yang diusung oleh Johan Galtung, seperti apa teori konflik yang diusung oleh Lewis A. Coser. Terakhir disimpulkan apa yang membedakan maupun kesamaan dari kedua teori yang diusung oleh kedua tokoh tersebut. Tujuan penulisan artikel ini yaitu untuk mengetahui bagaimana perbandingan teori konflik yang diusung oleh Johan Galtung dan Lewis A. Coser.

\section{B. METODE PENELITIAN}

Metode yang digunakan dalam penelitian artikel ini menggunakan metode penelitian kualitatif. Penelitian kualitatif merupakan penelitian yang digunakan untuk menyelidiki, menemukan, menggambarkan, dan menjelaskan kualitas atau keistimewaan dari pengaruh sosial yang tidak dapat dijelaskan, diukur atau digambarkan melalui pendekatan kuantitatif. ${ }^{5}$ Penelitian kualitatif juga disebut sebagai tradisi tertentu dalam ilmu pengetahuan sosial yang fundamental bergantung dari pengamatan pada manusia baik dalam kawasannya maupun dalam peristilahannya. ${ }^{6}$

Jenis penelitian dalam artikel ini menggunakan langkah studi pustaka (library research), karena dalam pengumpulan, menganalisis, dan mengelola data-data diambil dari studi literatur yang tertulis dan juga relevan. ${ }^{7}$ Sumber-sumber yang penulis ambil merupakan sumber-sumber yang relevan dengan tema judul penelitian, seperti buku, jurnal, ataupun artikel-artikel penelitian. Dalam pembahasan penelitian ini, penulis akan menjelaskan secara deskriptif dan analisis tentang studi komparatif teori konflik yang diusung oleh Johan Galtung dan Lewis A. Coser.

\footnotetext{
${ }^{5}$ Anwar Hidayat, "Penelitian Kualitatif: Penjelasan Lengkap", https://www.statistikian.com/2012/10/penelitian-kualitatif.html.

${ }^{6}$ Lexy J. Moleong, Metodologi Penelitian Kualitatif, (Bandung: PT Remaja Rosdakarya, April 2017), 4.

${ }^{7}$ Wahidmurni, "Pemaparan Metode Penelitian Kualitatif", Dosen Fakultas Ilmu Tarbiyah dan Keguruan, Universitas Maulana Malik Ibrahim Malang, Juli 2017, 4.
} 


\section{HASIL DAN PEMBAHASAN}

\section{Selayang Pandang Teori Konflik}

Sebelum melangkah pada pembahasan lebih mendalam tentang tema yang dikaji dalam tulisan ini, perlu adanya pengenalan terlebih dahulu apa itu konflik. Berbicara tentang konflik, secara etimologis, kata konflik berakar dari bahasa latin "con" yang berarti bersama, dan "fligere" yang berarti benturan/tabrakan. Namun istilah ini jika dipahami secara umum bermakna suatu tindakan/serangkaian peristiwa saling bertolakbelakang, pertentangan, pertikaian maupun disharmonisasi antar kelompok maupun individu dengan kelas-kelas tertentu. Hal ini bisa dipicu mulanya dari adanya pertentangan hingga sampai pada titik kulminasinya, yang salah satunya bisa menyebabkan peperangan dalam skala internasional. ${ }^{8}$

Dalam pandangan Dahrendorf mengenai konflik, ia dalam melihat masyarakat terbagi ke dalam dua rupa, pertama yaitu konflik, kedua yakni kesepakatan atau konsensus (consensus). Dahrendorf berpendapat bahwa, dalam suatu masyarakat tidak akan terjadi konlik jika sebelumnya tidak ada konsensus. Sebagai contoh: individu A dan individu B tidak akan pernah berkonflik jika sebelumnya belum pernah mengenal satu sama lain dan hidup berdampingan. Begitu pun dalam skala kelompok tertentu semisal komunitas remaja, komunitas suporter sepakbola maupun komunitas keagamaan sekali pun. Sebaliknya, adanya suatu konflik juga bisa mengantarkan terhadap konsensus. Semisal, adanya kerja sama saat ini yang dibangun oleh Jepang dan Amerika yang merupakan hasil konsensus yang dilakukan/dibangun setelah adanya perang agung yang menggemparkan dunia, yakni perang dunia ke-II.

Hal ini dalam pandangan Soejono Soekanto dalam karyanya yang bertajuk “Kamus Sosiologi”. Ia berpendapat bahwa konflik dipandang sebagai suatu proses dalam mencapai suatu kepentingan maupun tujuan dengan jalan mematikan/melemahkan lawan saingnya, bahkan tanpa sesekali mempedulikan nilai dan norma yang berlaku, baik agama maupun pemerintah. ${ }^{9}$ Berbeda dengan pendapat Lewis A. Coser tentang konflik, ia berpendapat bahwa konflik sosial merupakan upaya memperjuangkan pengakuan dan nilai yang sifatnya langka. Langkah yang ditempuh

\footnotetext{
${ }^{8}$ Akbar Kurniadi, dkk, "Transformasi Konflik Sosial Antar-Etnis Bali dan Lampung dalam Mewujudkan Perdamaian di Balinuraga Kecamatan Way Panji Kabupaten Lampung Selatan”, Universitas Pertahanan Indonesia, 9.

${ }^{9}$ Soerjono Soekanto, Kamus Sosiologi, (Jakarta: PT. Raja Grafindo Persada, 1993), 99.
} 
yaitu dengan menetralisir sumber-sumber masalah dan kekuasan hingga mengeliminir saingan politiknya. ${ }^{10}$

\section{Teori Konflik ala Johan Galtung}

Sebelum beranjak pada pembahasan teori menurut Johan Galtung, perlu kiranya mengenal singkat tentang latar belakangnya. Johan Galtung merupakan salah satu akademisi dan juga pemikir yang berpengaruh terhadap perdamaian yang terinspirasi dari tokoh besar perdamaian dunia yaitu Mahatma Ghandi. Dalam karyanya yang kerap kali dijadikan sebagai rujukan para akademisi, kebijakan pemerintah dan politisi di berbagai negara yaitu yang berjudul "Perdamaian dan Kekerasan". ${ }^{11}$ Dari sini hasil pemikiran Johan Galtung berperan penting terhadap keilmuan di berbagai dunia. Teori konflik yang populer dari Johan Galtung adalah teori konflik segitiga ABC.

Dalam menafsirkan konflik, Johan Galtung membangi tiga komponen utama yang terdiri dari $\mathrm{ABC}$, yang artinya $\mathrm{A}$ (attitude/sikap), B (behavior/perilaku), dan $\mathrm{C}$ (Contradiction/ kontradiksi atau pertentangan). Hal ini diambil oleh Johan Galtung dari komponen utama masalah/konflik dalam realitas kehidupan, yang pada akhirnya disebut dengan segitiga ABC. Namun, dalam ketiga komponen tersebut yang menempati urutan pertama dari komponen suatu konflik yaitu bermula dari kontradiksi, yang pada ahirnya urutannya sebagai berikut: Contradiction - Attitude Behavior. $^{12}$

Analisis Johan Galtung pada mulanya dalam menciptakan teori segitiga tersebut dimaksudkan ketika diterapkan dalam situasi peperangan, yang di dalamnya terdapat pertentangan pihak-pihak tertentu yang saling bertolak belakang. Akan tetapi, di sisi lain pemikiran Johan Galtung bahwasanya model yang ia ciptakan tersebut juga bisa diterapkan ketika menyelasaikan konflik/masalah lainnya, semisal diskriminasi, kekerasan dalam rumah tangga (KDRT), pelanggaran HAM, maupun mengatasi konflik di ruang lingkup sekolah. Pada umumnya, dalam menangani suatu konflik dapat menggunakan metode kekerasan ataupun yang sifatnya merusak. Akan tetapi,

\footnotetext{
${ }^{10}$ Teori konflik Lewis A. Coser, dalam http://crateridea.blog.uns.ac.id/2016/03/21/teori-konflik-lewis-acoser/, diakses pada 28 April 2020.

${ }^{11}$ Linda Dwi Eriyanti, "Pemikiran Johan Galtung Tentang Kekerasan dalam Perspektif Feminisme", Jurnal Hubungan Internasional, vol. 6, no. 1, April-September 2017, 1-2.

${ }^{12}$ Refia Juniarti Handrastin, Budi Purwoko, "Studi Kasus Dinamika”, 369.
} 
dalam persepsi orang secara umum, suatu konflik identik dengan tindakan kekerasan, dari sinilah Johan Galtung mencetuskan teorinya yang bisa menjelaskan bagaimana suatu konflik tersebut berlangsung. ${ }^{13}$

Dalam Webe and Galtung (2007), Johan Galtung menyatakan pendapatnya bahwasanya urutan konflik sebagaimana di atas: $\mathrm{C}-\mathrm{A}-\mathrm{B}$, pada mulanya konflik muncul secara objektif dari pihak tertentu, menemukan sesuatu dari luar, kehidupan sikap, mengambil bagian dalam pelaku konflik, ekspresi perilaku, baik itu secara fisik maupun lisan, dengan kekerasan ataupun non-kekerasan. Namun, di sini tidak menutup kemungkinan bahwa urutan $\mathrm{ABC}$ lainnya bisa juga diterapkan di suatu kondisi lain yang sifatnya empiris. Hal ini dikarenakan tiga komponen yang dicetuskan Galtung di atas saling berkaitan dan berpengaruh.

Adapun penjelasan/penjabaran lebih rincinya ketiga unsur teori konflik Galtung sebagai berikut; (a) Contradiction, merupakan pertentangan keras dan tajam yang muncul dalam suatu konflik. Hal ini yang kerap kali menjadi akar atau sumbu dari terjadinya suatu konflik; (b) Attitude, yaitu cara pihak yang tengah mengalami konflik dalam berpikir dan merasakan terhadap konflik yang tengah terjadi perseteruan dengan pihak atau kelompok yang lain; (c) Behavior, hal ini digambarkan sebagai suatu ekspresi dari konflik yang tengah terjadi baik secara fisik maupun verbal. Timbulnya tindakan/perilaku ketika sedang terjadi konflik interpersonal sangat mungkin dipengaruhi oleh sikap dan persepsi yang saling bertolak belakang/kontradiksi. ${ }^{14}$

\section{Pandangan Lewis A. Coser Tentang Teori Konflik}

Salah satu tokoh yang mencetuskan teori konflik selain Johan Galtung adalah Lewis A Coser yang lahir pada 27 November 1913 dari keluarga borjuis Yahudi. Dari sejarahnya atau latar belakang munculnya teori fungsional konflik Lewis A. Coser bermula pada melihat keadaan sosial politik pada masa itu. Pemikiran Lewis A. Coser tidak jauh berbeda dengan hasil pemikiran Talcot Parsons dan juga Robert K. Marton yang juga mengusung teori struktural fungsional dalam sosiologi Amerika pada Tahun 1950-an yang merupakan orientasi teoritis yang dominan. ${ }^{15}$

\footnotetext{
13 Ibid., 369.

14 Frans Pailin Rumbi, "Ma’bisara dengan Menggunakan Teori ABC dari Johan Galtung”, Teologi Kontekstual STAKN Toraja, 67.

${ }^{15}$ Khusniati Rofiah, "Dinamika Relasi Muhammadiyah dan NU dalam Perspektif Teori Konflik Fungsional Lewis A. Coser”, Kalam, vol. 6, no. 1, Desember 2016, 474.
} 
Teori yang diusung Lewis A. Coser lebih menekankan pada proses-proses sosial yang didasarkan pada konsensus atau nilai normatif, keselarasan dan keteraturan. Dalam pandangan teori Lewis A. Coser, masyarakat berada dalam kondisi/posisi yang damai, tentram, aman, bersatu tanpa adanya konflik satu pun. Proses konflik dilakukan dan dipandang sebagai suatu hal yang berupa masalah besar yang dapat mengusik, mengacaukan atau juga disfungsional terhadap keseimbangan sistem secara umum dan menyeluruh. Bahkan Lewis A. Coser mengkritik dan menolak pandangan sosiolog Amerika Serikat yang memiliki persepsi buruk terhadap fungsi dan konsep konflik sosial. Karena menurutnya, adanya konflik tidaklah semata-mata hanya akan berakhir pada kerusakan, disintegrasi, berkonotasi disfungsional di mana sistem konflik tersebut berlangsung, namun di sisi lain dari adanya konflik tersebut ada konsekuensikonsekuensi/dampak yang positif yang berpotensi menguntungkan sistem tersebut. ${ }^{16}$

Teori yang diusung Lewis A. Coser ini pertama kali diperkenalkan sekitar Tahun 1956 melalui buah karyanya yang diangkat dari tugas akhir disertasinya yang bertajuk The Function of Sosial Conflict. Teori ini bersifat naturalis dan termasuk dalam kategori teori konflik modern. Pandangan Lewis A. Coser lebih fokus/memusatkan perhatiannya terhadap fungsi-fungsi dari konflik itu sendiri yang nantinya dapat membawa pada penyesuaian sosial yang lebih baik dibandingkan hanya terfokus pada keadaan disfungsional, peperangan, kegaduhan dan sejenisnya sebagaimana teori-teori struktural lainnya ${ }^{17}$ yang secara umum suatu konflik dipandang sebagai sebuah fenomena yang berujung pada pertikaian dan tindakan kekerasan. ${ }^{18}$

Lewis A. Coser memandang hal ini sebagai sebuah perjuangan atas nilai-nilai dalam menuntut status kekuasaan serta sumber-sumber yang menetralisir misi musuh atau lawan dalam melukai kompetitornya. ${ }^{19}$ Ia kembali mengungkapkan dalam merangkum seluruh fenomena sebagaimana di atas tidak ada teori konflik sosial yang mampu merangkumnya. Analisa Lewis A. Coser tentang fungsi dari konflik sosial juga bisa dipandang sebagai suatu jalan pintas ataupun solusi terhadap perspektif-perspektif teeori konflik yang sifatnya radikal yang diusung dalam pandangan Marxis.

\footnotetext{
${ }^{16}$ Ibid., 475.

${ }^{17}$ Ibid., 478.

${ }^{18}$ Defa Ayu Triyana, “Analisis Poligami di Film Surga Yang Tak Dirindukan Studi Teori Konflik Lewis A. Coser", 2018.

${ }^{19}$ Dede Nova Andriyana, "Konflik Sosial dalam Novel Tan Karya Hendri Teja Melalui Teori Konflik Lewis A. Coser”, Piktorial: Jurnal Of Humanity, 110.
} 
Lewis A. Coser berpendapat bahwa ada fungsi sosial dalam suatu konflik. ${ }^{20}$ Dari sini ia memadukan dua teori, pertama fungsional struktural, kedua teori konflik. Maka dari itu, teori yang diusung Lewis A. Coser dikembangkan sehingga dikenal dengan fungsionalisme konflik sosial. ${ }^{21}$ Dari asumsi digabungnya atau dipadukannya kedua teori tersebut akan menjadi lebih kuat daripada masing-masing teori tersebut berdiri sendiri secara parsial. ${ }^{22}$ Dalam kedua teori tersebut mengandung sebuah kebenaran, namun juga tidak mampu menjabarkan realitas sosial secara keseluruhan, karena nyatanya masyarakat bisa saja sekali-kali terlibat dalam sebuah konflik, bahkan ada pula yang dengan adanya konflik tersebut muncullah kesepakatan-kesepakatan baru. ${ }^{23}$

\section{SIMPULAN}

Lebih sederhananya dari teori konflik yang diusung oleh Johan Galtung dengan teori segitiga $\mathrm{ABC}$-nya yang terdiri dari tiga komponen utama dalam memandang konflik, yaitu sikap, perilaku dan kontadiksi ataupun pertentangan. Johan Galtung menafsirkan suatu konflik menjadi tiga komponen tersebut yang saling berkaitan satu sama lain. Beda halnya dengan teori konflik yang dikemukakan oleh Lewis A. Coser yang dikenal dengan teori fungsionalisme konflik sosial, ia berpendapat bahwa dari adanya konflik tidak selalu terjerumus atau berakhir pada suatu tindakan fisik yang berupa kekerasan, peperangan, kerusakan dan lain sejenisnya. Akan tetapi dari adanya konflik tersebut nantinya akan menimbulkan hal positif pula yakni adanya kesepakatan-kesepakatan baru yang dapat diterapkan, solidaritas semakin tinggi, dan semakin menjadi sarana perekat sosial. Hasil penelitian ini diharapkan dapat menjadi perbendaharaan keilmuan sesuai dengan tematema yang berkaitang dengan konflik. Diharapkan pula peneliti selanjutnya untuk menemukan lebih banyak bahan-bahan kajian baru mengenai tema-tema yang berkaitan dengan konflik dan melakukan pengembangan-pengembangan sesuai dengan keadaan sosial yang dinamis.

\footnotetext{
${ }^{20}$ Robi Panggara, "Konflik Kebudayaan Menurut Teori Lewis Alfred Coser dan Relevansinya dalam Upacara Pemakaman (Rambu Solo') di Tana Toraja”, Jurnal Jaffray, vol. 12, no. 2, Oktober 2014, 292.

${ }^{21}$ Nur Azizah, "Pemikiran KH. Maimun Zubair Muntashor dan KH. Shinwan Adra'ie dalam Merespon Isu Bidah di Bangkalan Madura (Analisis Teori Konflik Sosial Alfred Coser", (Skripsi-Universitas Islam Negeri Sunan Ampel, Surabaya, 2020, 12.

${ }^{22}$ Mega Tri Purnami, dkk, "Representasi Hukum dalam Cerpen Hakim Sarmin Karya Agus Noor: Analisis Konflik Sosial Lewis A. Coser”, Jurnal Pendidikan Bahasa dan Sastra Indonesia Undiksha, vol. 9, no. 2, Agustus 2019, 233.

${ }^{23}$ Limas Dodi, "Sentiment Ideology: Membaca Pemikiran Lewis A. Coser dalam Teori Fungsional Tentang Konflik (Konsekuensi Logis dari Sebuah Interaksi di Antara Pihak Jamaah LDII dengan Masyarakat Sekitar Gading Mangu-Perak-Jombang”, Jurnal Al- 'Adl, vol. 10, no. 1, Januari 2017, 114.
} 


\section{DAFTAR PUSTAKA}

Andriyana, Dede Nova, "Konflik Sosial dalam Novel Tan Karya Hendri Teja Melalui Teori Konflik Lewis A. Coser”, Piktorial: Jurnal Of Humanity.

Azizah, Nur, "Pemikiran KH. Maimun Zubair Muntashor dan KH. Shinwan Adra'ie dalam Merespon Isu Bidah di Bangkalan Madura (Analisis Teori Konflik Sosial Alfred Coser”, (Skripsi-Universitas Islam Negeri Sunan Ampel, Surabaya, 2020.

Dodi, Limas, "Sentiment Ideology: Membaca Pemikiran Lewis A. Coser dalam Teori Fungsional Tentang Konflik (Konsekuensi Logis dari Sebuah Interaksi di Antara Pihak Jamaah LDII dengan Masyarakat Sekitar Gading Mangu-Perak-Jombang”, Jurnal Al-'Adl, vol. 10, no. 1, Januari 2017.

Eriyanti, Linda Dwi, "Pemikiran Johan Galtung Tentang Kekerasan dalam Perspektif Feminisme", Jurnal Hubungan Internasional, vol. 6, no. 1, April-September 2017.

Fitriani, dkk, "Membangun Relasi Umat Beragama Pasca Konflik Agama di Tanjungbalai”, Studia Sosia Religia, vol. 3, no. 1, Januari-Juni 2020.

Handrastin, Refia Juniarti, Budi Purwoko, "Studi Kasus Dinamika Psikologis Konflik Interpersonal Siswa Merujuk Teori Segitiga ABC Konflik Galtung dan Kecenderungan Penyelesaiannya pada Siswa Kelas XII Jurusan Multimedia (MM) di SMK Mahardika Surabaya", Jurnal BK Unesa, vol. 4, no. 2, 2014.

Hidayat, Anwar, "Penelitian Kualitatif: Penjelasan Lengkap", https://www.statistikian.com/2012/10/penelitian-kualitatif.html.

Indra Gunawan, Anton Saetban, dan Aiman Faiz, "Enhancing Religious Tolerance through Educators' Behaviors,” JPIS: Jurnal Pendidikan Ilmu Sosial 28, no. 1 (2019): 38 .

Kurniadi, Akbar, dkk, "Transformasi Konflik Sosial Antar-Etnis Bali dan Lampung dalam Mewujudkan Perdamaian di Balinuraga Kecamatan Way Panji Kabupaten Lampung Selatan”, Universitas Pertahanan Indonesia.

Moleong, Lexy J, Metodologi Penelitian Kualitatif, (Bandung: PT Remaja Rosdakarya, April 2017). 
Panggara, Robi, "Konflik Kebudayaan Menurut Teori Lewis Alfred Coser dan Relevansinya dalam Upacara Pemakaman (Rambu Solo') di Tana Toraja”, Jurnal Jaffray, vol. 12, no. 2, Oktober 2014.

Purnami, Mega Tri, dkk, "Representasi Hukum dalam Cerpen Hakim Sarmin Karya Agus Noor: Analisis Konflik Sosial Lewis A. Coser", Jurnal Pendidikan Bahasa dan Sastra Indonesia Undiksha, vol. 9, no. 2, Agustus 2019.

Rofiah, Khusniati, "Dinamika Relasi Muhammadiyah dan NU dalam Perspektif Teori Konflik Fungsional Lewis A. Coser”, Kalam, vol. 6, no. 1, Desember 2016.

Rumbi, Frans Pailin, “Ma’bisara dengan Menggunakan Teori ABC dari Johan Galtung”, Teologi Kontekstual STAKN Toraja.

Soekanto, Soerjono, Kamus Sosiologi, (Jakarta: PT. Raja Grafindo Persada, 1993).

Teori konflik Lewis A. Coser, dalam http://crateridea.blog.uns.ac.id/2016/03/21/teorikonflik-lewis-a-coser/, diakses pada 28 April 2020.

Triyana, Defa Ayu, “Analisis Poligami di Film Surga Yang Tak Dirindukan Studi Teori Konflik Lewis A. Coser", 2018.

Wahidmurni, “Pemaparan Metode Penelitian Kualitatif”, Dosen Fakultas Ilmu Tarbiyah dan Keguruan, Universitas Maulana Malik Ibrahim Malang, Juli 2017.

Zattullah, Nour, "Konflik Sunni-Syiah di Sampang Ditinjau dari Teori Segitiga Konflik Johan Galtung”, Jurnal Ilmu Budaya, vol. 9, no. 1, 2021. 